\title{
Population trends of Black Vulture Aegypius monachus in Dadia Forest, north-eastern Greece following the establishment of a feeding station
}

\author{
CHRISTOS G. VLACHOS, DIMITRIS E. BAKALOUDIS \\ and GRAHAM J. HOLLOWAY
}

\section{Summary}

Dadia Forest in north-eastern Greece is well known for its diversity of breeding birds of prey. In 1980, the area was declared a wildlife reserve. One of the most endangered species at that time was the Black Vulture Aegypius monachus. To help the population of Black Vultures a feeding station was established in 1987. A monitoring programme from 1984 until present indicates that the operation of the feeding station has coincided with an increase in the numbers of Black Vultures wintering in Dadia by nearly threefold, an increase in the number of breeding pairs from 10 to 21 , and an increase in breeding success from $40 \%$ to a peak of $95 \%$. A slight faltering in the continued rise in the numbers of Black Vultures in Dadia is attributed to a poisoning event in 1995.

\section{Introduction}

The Black Vulture Aegypius monachus is the most endangered species of vulture in Greece. There is historical evidence that Black Vultures were once widespread in the country, distributed across the entire mainland and even some islands (Handrinos and Akriotis 1997). The population of this species, as with many other large raptors, declined sharply across Europe between 1950 and 1970. Today, apart from Spain (900-1000 pairs), Greece, Russia and the Ukraine (4670 pairs combined) are the only sites in Europe where small populations of the Black Vulture still survive (Tucker and Heath 1994), although an unknown number, probably in the hundreds, also exists in Turkey (Tucker and Heath 1994).

There are two isolated colonies of Black Vultures in Greece. One, discovered in 1983 on Mount Olympus, consists of only 6 or 7 birds. In 1987 two breeding pairs were established there and successfully reared two young (Hallman 1992). The other colony is in Dadia Forest, north-eastern Greece, and represents the most south-easterly breeding population in Europe (Cramp and Simmons 1980). In 1984, it was estimated that four pairs bred there (Murray and Vlachos 1985, unpublished data). There are probably two principal reasons for the decline of the Black Vulture in Greece: the loss of habitat through the destruction of forests, particularly of large trees for nesting, and a decline in the availability of food (Handrinos 1985), both through the reduction in numbers of shepherded live- 
stock and the control or eradication of large carnivores, such as wolves Canis lupus, jackals Canis aureus and foxes Vulpes vulpes. The vultures benefited from the presence of carnivores through the availability of prey remains after the predators had eaten their fill. For example, there is a correlation between the number of cattle per hectare and the number of Black Vultures. Between 1940 and 1980, cattle numbers declined by $74 \%$ in Spain (de Juana and de Juana 1984) and this was associated with a substantial decline in the numbers of Black Vultures. In the vicinity of Dadia Forest prior to 1940, more than 15,000 sheep and goats were tended (S. Adamantopoulou and E. Androukaki 1989, unpublished data) and were moved around in nomadic flocks in search of suitable grazing. According to anecdotal evidence from old shepherds, Black Vultures were very common in the area after the second world war. Many sheep and goats died and were left behind providing the vultures with ample food, but after 1960 there was a gradual decline in the number of livestock in the region.

The grazing of livestock profoundly affected the structure of the forest around Dadia and produced a patchwork of different types of habitats, supporting 2022 raptor species (Hallman 1979). In 1980 the forest around Dadia village was declared a reserve for wildlife. As part of a management plan for the area, two sections of the forest, coinciding with high densities of breeding raptors, were established as protected areas where human activities were restricted. In 1984 10 pairs of Black Vultures attempted to breed, but only four pairs were successful. It was possible that the poor breeding success was partly due to low food supplies and so, in 1987, a feeding station was established by the local forestry service. Cattle and horse carcasses were taken every two weeks or so from the local abattoir and dumped at the feeding station. To keep carnivorous mammals away from the meat a perimeter fence was erected.

The purpose of the present study was to assess the affects of the establishment of the feeding station on the numbers of Black Vultures breeding in the area and visiting the feeding station during the winter.

\section{Study area and methods}

The study area is located in the central part of Evros Province, north-eastern Greece $\left(40^{\circ} 59^{\prime}\right.$ to $41^{\circ} 15^{\prime} \mathrm{N}, 26^{\circ} 19^{\prime}$ to $\left.26^{\circ} 36^{\prime} \mathrm{E}\right)$ and covers approximately 37,000 ha $(7,250$ ha is a protected area). Situated on the southern edge of the Rhodopi mountain chain, it ranges from 20 to $700 \mathrm{~m}$ above sea-level. The whole area is criss-crossed with steep valleys and the climate is submediterranean with a strong continental character: dry summer and cold winter. The minimum mean monthly temperature is $-1.8^{\circ} \mathrm{C}$ (January) and the maximum mean monthly temperature is $30.4{ }^{\circ} \mathrm{C}$ (August). Northerly winds predominate and the annual precipitation is about $740 \mathrm{~mm}$. The area is characterized by a mosaic of habitats dominated by woodlands.

Data on the Black Vulture population were collected from 1984 to 1997, inclusive. Each year at the beginning of the breeding season (end January, beginning February) the territories of active pairs were located by noting the soaring territorial behaviour of the adults prior to nest building. Nesting trees were found through observation at a safe distance so as not to disturb the birds. All territories were checked during the breeding season for incubating vultures and later for 
Table 1. Maximum number of wintering individuals, number of breeding pairs and breeding success of Black Vulture Aegypius monachus in Dadia forest, north-eastern Greece from 1984 to 1997

\begin{tabular}{lcccc}
\hline Year & $\begin{array}{c}\text { Number of } \\
\text { individuals (max.) }\end{array}$ & $\begin{array}{c}\text { Number of } \\
\text { breeding pairs }\end{array}$ & $\begin{array}{c}\text { Number of } \\
\text { young fledged per nest }\end{array}$ & $\begin{array}{c}\text { Breeding success } \\
(\%)\end{array}$ \\
\hline 1984 & 24 & 10 & 4 & 40.0 \\
1985 & 22 & 11 & 5 & 45.5 \\
1986 & 26 & 11 & 6 & 54.5 \\
1987 & 20 & 12 & 6 & 50.0 \\
1988 & 44 & 13 & 8 & 61.5 \\
1989 & 57 & 13 & 11 & 84.6 \\
1990 & 48 & 13 & 10 & 76.9 \\
1991 & 46 & 14 & 13 & 92.9 \\
1992 & 50 & 16 & 13 & 81.2 \\
1993 & 62 & 19 & 18 & 94.7 \\
1994 & 65 & 20 & 19 & 95.0 \\
1995 & 60 & 20 & 15 & 75.0 \\
1996 & 68 & 18 & 10 & 55.6 \\
1997 & 59 & 21 & 11 & 52.4 \\
\hline
\end{tabular}

the presence of successfully reared young. Observations were made from a suitable vantage point at a distance using $10 \times 42$ binoculars. In addition to breeding success, the maximum numbers of vultures visiting the feeding station during each winter period (December-February) were also noted. From 1984 to 1986 prior to the establishment of the feeding station, the maximum number of vultures present in the area was noted from numbers congregating at naturally distributed carcasses.

\section{Results}

Table 1 shows the number of breeding pairs of Black Vultures in Dadia Forest from 1984 to 1997 . The number of pairs attempting to breed rose steadily from 10 in 1984 to 21 in 1997 . Table 1 also shows the proportion of pairs successfully rearing young (a pair normally rears one chick per season). The success rate rose from $40 \%$ in 1984 to a peak of $95 \%$ in 1993 and 1994. For the last two years of the survey (1996 and 1997) the breeding success rate fell back to around 60\%. The combination of a higher number of breeding attempts and higher rate of success has resulted in a substantial increase in the number of young birds leaving the nest (Table 1 ). The number of fledglings rose from just four in 1984 to a peak of 19 in 1994 .

Figure 1 shows the change in the maximum number of Black Vultures using the feeding station during the winter. In 1984, a maximum of only 24 was noted in Dadia feeding on dead animals. This number rose fairly steadily to a peak of 69 present at the feeding station in 1996.

\section{Discussion}

Just prior to the declaration of reserve status, Hallman (1979) estimated that there were 26 individual Black Vultures in the area. Even though very few, it still constituted the majority of individuals in south-eastern Europe. The main factor 


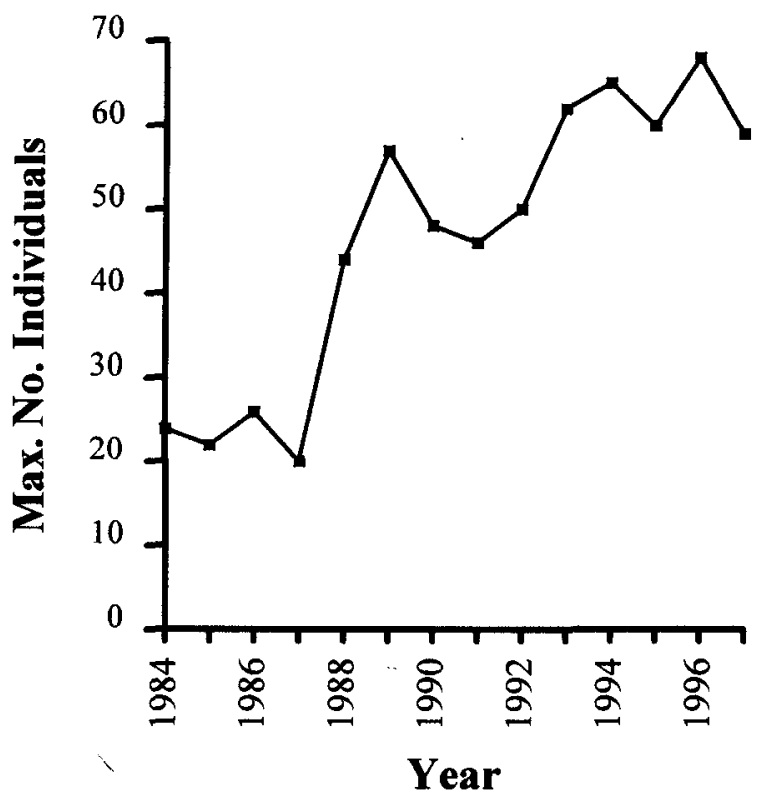

Figure 1. Maximum number of individuals of Black Vulture Aegypius monachus observed at carrion during the winter periods of 1984 to 1997 in Dadia Forest, north-eastern Greece.

limiting vulture populations is thought to be food availability (Newton 1979, 1991), although other factors, such as nest site availability may also play a role. Between 1980 and 1987 , the maximum number of individuals noted in Dadia Forest during the winter period was 26 individuals. Disturbance through, for example, forest exploitation can result in breeding failure (Garzón 1974, Hiraldo 1974), but the establishment of the two large protected areas within the Dadia reserve should have provided ample breeding opportunities. Hence it was considered likely that the lack of significant increase in population number was due to food shortage. To alleviate this the feeding station was established and in just two years the population more than doubled. Over the next 10 years, the population size continued to increase to a maximum just under 70 individuals (Figure 1). The number of breeding pairs also increased, especially between 1990 and 1994 (Table 1). In 1994, there were 20 pairs in Dadia alone, hence Tucker and Heath's (1994) estimate of 10-14 pairs for the whole of Greece was pessimistic. Finally, the breeding success increased from around 50\% in 1987 to $95 \%$ in 1993 and 1994 (Table 1). All of these factors suggest that the feeding station had major beneficial effects on the size and breeding success of the birds.

The increase in the breeding population and increased breeding success (Table 1) did not continue after 1994. There are two possible reasons for this. In 1995 at the beginning of the breeding season, seven Black Vultures (and one Golden Eagle Aquila chrysaetus) were found dead through eating meat laced with carbofuran. It is possible that this poisoning was directed against mammalian predators as 11 foxes were also poisoned. This event coincided with a decline in the breeding success of the vultures from $95 \%$ to $75 \%$. The next year, 1996, saw the first reduction in the number of breeding pairs for 13 years and a further reduction 
in breeding success to just $55 \%$. In 1997, the number of breeding pairs increased again to a new peak since the start of the monitoring programme, but again breeding success was relatively low (Table 1 ). It is possible that this was not linked to the poisoning event two years previously but to unusually low temperatures and heavy snowfalls in Dadia Forest, especially during March and April at a time when eggs or, later, small nestlings would have been vulnerable to chilling. Newton and Marquiss (1986) point out that the productivity of many raptors can be severely affected by weather conditions. Black Vultures are largely sedentary across most of their range. This fact coupled with their willingness to congregate at food supplies make local populations very susceptible to poisoning events. For example, in 1989 the small population at Mount Olympus collapsed when at least five birds were poisoned (Hallman 1992).

According to Terrasse (1985) and Wilbur et al. (1974), the establishment of feeding stations can be an effective tool in encouraging vulture populations and it is clear that the feeding programme in Dadia Forest has been a factor in the recovery of the Black Vulture population. However, some authors have raised a number of objections to supplementary feeding (Koford 1953). For example, McMillan (1965) expressed fears that it may reduce the natural survival abilities of the Californian Condor Gymnogyps californianus, whilst Houston (1978) found that Griffon Gyps fulvus and Egyptian Neophron percnopterus Vultures may suffer from calcium deficiency. The establishment of feeding stations does not always have an effect on vulture populations. For example, feeding stations were set up in a region of northern Spain for the benefit of Griffon Vultures but here, in contrast to the current study, the population did not change (Donázar and Fernández 1990). In this case it was concluded that the problem was not a shortage of food and that other factors were limiting population growth.

The Black Vulture was formally listed as Globally Threatened (Collar and Andrew 1988), but now its status has changed and it is categorized as Near Threatened (Collar et al. 1994). The change in status is due to increases in population numbers partly as a result of conservation measures taken as described in the present study. However, although the feeding station in Dadia Forest has been a success as far as the Black Vulture is concerned, the region contains a number of other endangered and rare bird of prey species. Further investigation is required to establish whether the feeding station and the presence of a concentration of vultures has had an effect on these species, be it beneficial or detrimental.

\section{Acknowledgements}

We are most grateful to the Greek Forestry Service for permission to carry out this study. We are also grateful to K. Poirazidis, T. Skartsi, K. Pistolas and P. Babakas for supplying us with useful information. Funding for D. Bakaloudis was provided by National Metsovio Polytechnio, Rectorate, Department of Commisariat, Athens, Greece.

\section{References}

Collar, N. J. and Andrew, A. (1988) Birds to watch: the ICBP World check-list of threatened birds. Cambridge U.K.: ICBP (Technical Publication 8). 
Collar, N. J., Crosby, M. J. and Stattersfield, A. J. (1994) Birds to watch: the World list of threatened birds. Cambridge U.K.: BirdLife International (BirdLife Conservation Series 4).

Cramp, S. and Simmons, K. E. L. (1980) Handbook of the birds of Europe, the Middle East and North Africa. II. Hawks to Bustards. Oxford: Oxford University Press.

de Juana, E. and de Juana, F. (1984) [Livestock and the distribution and abundance of Griffon and Black vulture in Spain]. Pp. 32-45 in Centre Recerca Protecció Rapinyaires, ed. [Mediterranean raptors II.], Barcelona: CRPR. (In Spanish.)

Donázar, J. A. and Fernández, C. (1990) Population trends of the Griffon Vulture, Gyps fulvus, in Northern Spain between 1969 and 1989 in relation to conservation measures. Biol. Conserv. 53: 83-91.

Garzón, J. (1974) [A contribution to the study of status, feeding and protection of Falconiformes in Central Spain.] Ardeola 19: 279-330. (In Spanish).

Hallman, B. (1979) Guidelines for the conservation of birds of prey in Evros. A report of IUCN/WWF Project 1684.

Hallman, B. (1992) Black Vulture Recovery Programme at Mount Olympus. H. S. P. N. Bull. 58: $36-37$.

Handrinos, G. (1985) The status of vultures in Greece. Cambridge, U.K.: International Council for Bird Preservation (Technical Publication 5).

Handrinos, G. and Akriotis, T. (1997) The birds of Greece. London: Cromwell Press.

Hiraldo, F. (1974) [Breeding colonies and census of Black Vultures, Aegypius monachus, in Spain] Nat. Hispanica 2: 3-31. (In Spanish).

Houston, D. C. (1978) The effects of food quality on breeding strategy in Griffon Vultures (Gyps spp. ). J. Zool. Lond. 186: 175-184.

Koford, C. (1953) The California Condor. Natl. Audubon Soc. Rep. 4.

McMillan, I. (1965) An objection to feeding California Condors. Defenders Wildl. News 40: $45-46$.

Newton, I. (1979) Population ecology of raptors. London: Poyser.

Newton, I. (1991) Population limitation in birds of prey: a comparative approach. Pp. 321 in C. M. Perrins, J. D. Lebreton and G. J. M. Hirons, eds. Bird population studies: relevance to conservation and management. Oxford: Oxford University Press.

Newton, I. and Marquiss, M. (1986) Population regulation in sparrowhawks. J. Anim. Ecol. 55: 463-480.

Terrasse, J. F. (1985) The effects of artificial feeding on Griffon, Bearded and Egyptian Vultures in the Pyrenees. Pp. 429-430 in I. Newton and R. D. Chancellor, eds. Conservation studies on raptors. Norwich: Paston Press.

Tucker, G. M. and Heath, M. F. (1994) Birds in Europe. Their conservation status. Cambridge, U.K.: BirdLife International (BirdLife Conservation Series 3 ).

Wilbur, S. R.; Carrier, W. D. and Borneman, J. C. (1974) Supplemental feeding program for Californian Condors. J. Wildlife Manag. 38: 343-346.

\section{CHRISTOS G. VLACHOS}

Department of Forestry and Natural Environment, Aristotelian University of Thessaloniki, P. O. Box 241, Thessaloniki 54006, Greece.

DIMITRIS E. BAKALOUDIS and GRAHAM J. HOLLOWAY ${ }^{1}$

The Division of Zoology, School of Animal and Microbial Sciences, The University of Reading, Whiteknights, P. O. Box 228, Reading RG6 6AJ, U.K.

${ }^{1}$ Corresponding author (e-mail: g.j.holloway@reading.ac.uk) 